\title{
Potensi Wisata Alam Air Terjun Kuning Sebagai Daya Tarik Wisata Alam Di Kawasan Desa Taman Bali, Kecamatan Bangli, Kabupaten Bangli
}

\author{
Ni Putu Eka Oktaviantari, Damiati, Ni Made Suriani, \\ Jurusan Pendidikan Teknologi Industri \\ Universitas Pendidikan Ganesha \\ Singaraja, Indonesia
}

E-mail: ekaoktaviantari71@gmail.com,damiati@undiksha.ac.id

imade.suriani@undiksha.ac.id,

\begin{abstract}
ABSTRAK
Tujuan dari penelitian ini adalah untuk mengetahui potensi objek wisata alam Air Terjun Kuning sebagai daya tarik wisata alam di kawasan Desa Taman Bali Kecamatan Bangli Kabupaten Bangli. Dalam penelitian ini, peneliti menggunakan tiga metode yaitu metode wawancara, observasi dan analisis SWOT.

Hasil penelitian ini yaitu (1) kondisi fisik Air Terjun Kuning memiliki ketinggian 25 meter dengan kedalaman 3 meter, dan tempat peristirahatan seluas 1 are, (2) keadaan lingkungan disekitar air terjun masih sangat alami, (3) Keunikan Air Terjun Kuning memiliki tempat sumber mata air minum dan melukad yang disakralkan, yang digunakan sebagai tempat melukad, (4) Kegiatan yang dapat dilakukan di Air Terjun Kuning yaitu jasuzz dan pembuatan vlog, (5) Fasilitas penunjang Air Terjun Kuning yaitu pos informasi, tempat parkir, restaurant. Berdasarkan hasil penelitian diatas dapat disimpulkan bahwa Air Terjun Kuning memiliki potensi sebagai daya tarik wisata alam.
\end{abstract}

Kata Kunci : Air Terjun Kuning, Potensi Wisata Air Terjun Kuning, Daya Tarik Wisata Alam

\begin{abstract}
The purpose of this study was to find out the potential of the Yellow Waterfall as a natural tourist attraction in the area of Taman Bali Village, Bangli District, Bangli Regency. In this study, researchers used three methods, namely the method of interview, observation and SWOT analysis.

The results of this study are (1) the physical condition of Yellow Waterfall has a height of 25 meters with a depth of 3 meters, and a resort area of 1 acre, (2) the environment around the waterfall is still very natural, (3) The uniqueness of Yellow Waterfall has its source sacred drinking water and burdens, which are used as a place of burial, (4) Activities that can be done in Waterfall Kuning are jasuzz and vlog making, (5) Yellow Waterfall supporting facilities, namely information posts, parking lots, restaurants. Based on the results of the above research it can be concluded that Yellow Waterfall has potential as a natural tourist attraction.
\end{abstract}

Keywords: Yellow Waterfall, Yellow Waterfall Tourism Potential, Nature Tourism Attraction 
Jurnal Bosaparis: Pendidikan Kesejahteraan Keluarga

Volume 10, Nomor 2, Juli 2019

\section{PENDAHULUAN}

Pariwisata merupakan suatu gejala yang terjadi di muka bumi ini yang timbul karena adanya aktivitas manusia untuk memenuhi kebutuhannya. Sebagai suatu aktivitas manusia, pariwisata selalu berkaitan dengan produk serta jasa yang dikelola oleh manusia. Pariwisata merupakan sektor yang memiliki pertumbuhan yang sangat cepat dan telah terjadi salah satu industri terbesar di dunia yang merupakan andalan dalam menghasilkan devisa di berbagai Negara. Pertumbuhan pariwisata yang sangat cepat, telah menarik perhatian Indonesia khususnya Provinsi Bali. Melihat kemajuan industri pariwisata yang begitu pesat, pada tahun 1999 Pemerintah menerbitkan Undang-undang No. 22 Tahun 1999 tentang otonomi daerah yang memberikan kesempatan bagi masing-masing daerah untuk mengelola dan mengembangkan sendiri potensi pariwisata yang ada di daerahnya. Adanya UU No. 22 Tahun 1999 memberikan kesempatan kepada Provinsi Bali untuk mengembangkan dan mengelola sendiri potensi alam dan budaya yang dimiliki. Pariwisata di Bali sudah terkenal baik di Indonesia maupun mancanegara.

Perkembangan pariwisata di Bali berkembang dengan baik tidak hanya dikarenakan pemandangan alam yang indah tetapi juga dikarenakan keragaman budaya, tradisi, seni, keyakinan beragama dan keramah tamahan penduduknya. Selain itu akomodasi serta sarana dan prasarana pendukung pariwisata sangat lengkap seperti hotel, restoran pusat rekreasi, layanan informasi wisata, hingga sewa mobil dan motor.

Adanya perkembangan pariwisata dan banyaknya wisatawan yang berkunjung ke Bali, kabupaten-kabupaten dan kota yang ada di bali menjadi termotivasi untuk mengembangkan serta mengelola potensi wisata yang dimiliki menjadi objek dan daya tarik wisata, baik yang berasal dari alam dan budaya masyarakatnya. Salah satu kabupaten yang termotivasi dan mulai mengembangkan potensinya adalah kabupaten Bangli.

Kabupaten Bangli dikenal sebagai salah satu tempat destinasi kunjungan wisata yang memiliki sumber daya pariwisata yang asri dan menarik. Kabupaten Bangli berbatasan dengan Kabupaten Buleleng di sebelah utara, kabupaten Klungkung dan Karangasem di timur, dan kabupaten Klungkung, Gianyar di selatan serta Badung dan Gianyar di sebelah barat. Kabupaten Bangli memiliki banyak objek wisata yang menarik seperti gunung dan danau batur (Kintamani), Desa Penglipuran, Pura Kehen, Pura Ulun Danu Batur, Pemakanan Trunyan, Air Terjun Kuning, Pura Tirtha Sudamala, Penangkaran Kopi Luwak, Pemandian Air Panas Toya Bungkah, Air terjun Tukad Cepung, dan masih banyak lainnya yang membuktikan bahwa Kabupaten Bangli sangat tinggi berpotensi sebagai daerah tujuan wisata dunia.Kabupaten Bangli mempunyai 4 kecamatan, 4 kelurahan dan 56 desa. Kecamatan-kecamatan tersebut adalah Kintamani, Susut, Tembuku dan Bangli. Adapun desa-desa yang ada di bangli yaitu : Desa Bebalang, Desa Bunutin, Desa Cempaga, Desa Kawan, Desa Kayubihi, Desa Kubu, Desa Landih, Desa Pengotan, Desa Taman Bali, dan lain-lain.

Objek wisata merupakan prospek yang bagus untuk digali potensinya. Pada umumnya orang memberi padangan kata wisata dengan rekreasi, wisata adalah sebuah perjalanan, namun tidak semua perjalanan dapat dikatakan wisata (Suyitno,2001). Menurut Fandeli (2001), wisata adalah perjalanan atau sebagai dari kegiatan tersebut dilakukan secara sukarela serta bersifat sementara untuk menikmati objek dan daya tarik wisata. Menurut Suryo Sakti (2012) objek dan daya tarik wisata adalah suatu bentukan yang berhubungan, yang dapat menarik wisatawan atau pengunjung untuk datang ke suatu atau tempat tertentu. Objek dan daya tarik wisata dapat dibedakan 
menjadi 3 (tiga) yaitu 1) objek wisata alam, objek wisata alam adalah sumber daya alam yang berpotensi serta memiliki daya tarik bagi pengunjung baik dalam keadaan alami maupun setelah ada usaha budi daya, 2) objek wisata sosial budaya, objek wisata sosial budaya dapat dimanfaatkan sebagai objek dan daya tarik wisata meliputi museum, peninggalan sejarah, situs arkeologi, upacara adat, kerajinan dan seni pertunjukkan, 3) objek wisata minat khusus, objek wisata minat khusus merupakan jenis wisata yang baru dikembangkan di Indonesia. Wisata ini lebih diutamakan pada wisatawan yang mempunyai motivasi khusus. Salah satu prospek wisata di Kabupaten Bangli yang sangat berpotensi yaitu wisata alam yang bertempat di Desa Taman Bali, yaitu wisata air terjun kuning.

Objek Wisata Air Terjun Kuning ini berada di Dusun Kuning, Desa Taman Bali, Kecamatan Bangli, Kabupaten Bangli. Lokasi air terjun ini memang cukup tersembunyi berada di dasar lembah, suasananya tenang, alamnya masih asri terlihat begitu cantik dan alami. Selain menampilkan Objek Wisata Alam yang indah, Air Terjun Kuning ini juga memiliki tempat melukat (tempat membersihkan diri secara rohani) secara Hindu. Berdasarkan hasil wawancara dengan masyarakat desa yang bekerja di objek wisata ini tanggal 29 Januari 2019, 14 April 2019, 5 Juni 2019 tingkat

Tabel 1. Kunjungan Ke Objek Wisata Air Terjun Kuning Pada Tahun 2015-2018 Yaitu

\begin{tabular}{|c|c|c|c|c|}
\hline \multirow{2}{*}{ NO } & \multirow{2}{*}{ TAHUN } & \multicolumn{2}{|c|}{ WISATAWAN } & \multirow{2}{*}{ JUMLAH } \\
\hline & & DOMESTIK & ASING & \\
\hline & 2015 & 1.490 & 720 & 2.210 \\
\hline & 2016 & 1.860 & 947 & 2.807 \\
\hline & 2017 & 2.291 & 1.232 & 3.523 \\
\hline & 2018 & 2.447 & 1.308 & 3.755 \\
\hline
\end{tabular}

Sumber : Hasil Wawancara Dengan Sumarti Air Terjun

Dari data di atas, dapat disimpulkan bahwa objek wisata Air Terjun Kuning masih belum sepenuhnya diketahui keberadaannya oleh sebagian besar wisatawan yang berkunjung ke Kabupaten Bangli, khususnya Desa Taman Bali karena masyarakat setempat belum mengembangkan objek wisata Air Terjun Kuning sebagai salah satu objek wisata alam di Desa Taman Bali, Kecamatan Bangli, Kabupaten Bangli.

Menyadari tingkat kunjungan wisatawan ke objek wisata Air Terjun Kuning dikategorikan sedikit, masyarakat setempat belum memanfaatkan objek wisata ini sebagai mata pencaharian dengan mempromosikan objek wisata Air Terjun Kuning dilihat dari sedikitnya kunjungan wisatawan. Mayoritas masyarakat setempat lebih mengandalkan sektor pertanian dan peternakan. Penghasilan dari masyarakat yang mengandalkan sektor pertanian adalah padi.

Begitu pula dengan masyarakat yang mengandalkan sektor peternakan. Penghasilan dari masyarakat yang mayoritasnya sebagai peternak adalah ayam dan bebek. Padahal sebenarnya Air Terjun Kuning ini dapat digali potensinya untuk dijadikan sebagai lapangan kerja.

Mengetahui informasi, situasi dan kondisi tersebut peneliti tertarik untuk menggali potensi yang dimiliki oleh Air Terjun Kuning. Dengan melakukan penelitian deskriptif kualitatif dengan judul "Potensi Air Terjun Kuning Sebagai Daya Tarik Wisata Alam di Kawasan Desa Taman Bali, Kecamatan Bangli, Kabupaten Bangli". Adapun permasalahan yang telah ditemukan oleh peneliti yaitu : Bagaimana potensi wisata alam Air Terjun Kuning sebagai daya tarik wisata alam di kawasan 
Jurnal Bosaparis: Pendidikan Kesejahteraan Keluarga

Volume 10, Nomor 2, Juli 2019

\section{Desa Taman Bali Kecamatan Bangli METODE PENELITIAN}

Jenis penelitian yang digunakan dalam penelitian ini adalah penelitian diskritif kualitatif yang memanfaatkan sumber daya alam. (Sugiyono, $2015: 224$ ) metode pengumpulan data merupakan langkah yang paling strategis dalam penelitian, karena tujuan utama dari penelitian adalah mendapatkan data. Tanpa mengetahui teknik pengumpulan data, maka peneliti tidak akan mendapatkan data yang memenuhi standar data yang ditetapkan

Metode pengumpulan data yang digunakan adalah metode observasi dan metode wawancara.

1. Metode observasi

Metode observasi dilakukan oleh peneliti dengan melakukan pengamatan langsung ke Air Terjun Kuning untuk mendapatkan data terkait mengenai kondisi fisik air terjun kuning, keadaan lingkungan dan keunikan dari air terjun kuning.

\section{Metode wawancara}

Metode wawancara yang digunakan dalam penelitian ini adalah wawancara terstruktur. Metode wawancara dilakukan dengan mengajukan pertanyaanpertanyaan yang sudah dirancang peneliti Tabel 2. Kisi-Kisi Instrumen Penelitian
Kabupaten Bangli. terkait mencari data mengenai potensi objek wisata air terjun kuning.

Waktu pelaksanaan penelitian dilakukan pada tahun 2018 - 2019. Berikut jadwal kegiatan penelitian.

Variabel penelitian dapat diartikan sebagai target dari suatu yang akan diteliti. Dalam penelitian ini terdapat satu variabel yaitu potensi wisata alam air terjun kuning sebagai daya tarik wisata alam.

Adapun instrumen penelitian yang akan digunakan dalam pencarian data adalah menggunakan lembar observasi dan pedoman wawancara lembar observasi digunakan untuk mengambil data mengenai kondisi fisik air terjun kuning, keadaan lingkungan dan keunikan dari air terjun kuning sedangkan lembar wawancara digunakan untuk mencari data mengenai potensi objek wisata air terjun kuning. Dalam penelitian ini, peneliti mendapatkan sumber informasi dari masyarakat Desa Taman Bali selaku pengelola objek wisata alam air terjun kuning.

Menurut Yoeti, 2006 daya tarik wisata alam adalah sumber daya alam yang berpotensi serta memiliki daya tarik bagi pengunjung baik dalam keadaan alami Maupun setelah ada usaha budi daya.

\begin{tabular}{|c|c|c|c|}
\hline Variabel & $\begin{array}{c}\text { Sub } \\
\text { Variabel }\end{array}$ & Indikator & Metode \\
\hline \multirow{5}{*}{$\begin{array}{c}\text { Potensi } \\
\text { wisata alam } \\
\text { air terjun } \\
\text { Kuning } \\
\text { sebagai } \\
\text { daya tarik } \\
\text { wisata alam }\end{array}$} & \multirow{5}{*}{$\begin{array}{l}\text { Daya tarik } \\
\text { wisata } \\
\text { alam }\end{array}$} & Flora dan Fauna & \\
\hline & & Keunikan & \\
\hline & & Air terjun & Observasi \\
\hline & & Pemandangan Sawah & Wawancara \\
\hline & & $\begin{array}{l}\text { Kegiatan yang dapat } \\
\text { dilakukan di air terjun } \\
\text { kuningan }\end{array}$ & \\
\hline
\end{tabular}

Data-data yang telah diperoleh melalui metode observasi dan metode wawancara selanjutnya akan dianalisis secara deskriptif-kualitatif dengan analisis SWOT, diantaranya (1) Kekuatan (Strenghts) dimana dalam analisis ini akan digunakan 
untuk mencari keadaan lingkungan, flora dan hutan; (2) Kelemahan (Weakness) dimana analisis ini akan digunakan untuk mencari fauna; (3) Peluang (Opportunities) dimana dalam analisis ini akan digunakan untuk mencari sumber mata air dan air terjun; (4) Ancaman (Threats) dimana dalam analisis ini akan digunakan untuk mencari pemandangan sawah. Data-data tersebut kemudian akan dipilah untuk memperoleh data yang sesuai dengan HASIL DAN PEMBAHASAAN HASIL

Berdasarkan acuan-acuan yang digunakan untuk memperoleh data yang valid, akan di jabarkan sebagai berikut :

\subsubsection{Strenght}

Berdasarkan hasil penelitian terdapat beberapa faktor yang dapat menjadi kekuatan bagi Air Terjun Kuning untuk menjadi objek wisata alam yang menarik untuk dikunjungi.

\subsubsection{Flora dan Fauna}

Air Terjun Kuning memiliki beberapa jenis fauna dilingkungan sekitarnya seperti burung, kadal, biawak dan kera yang sangat dilindungi. Terdapat banyak jenis flora seperti tumbuhan lumut, paku, pepaya, mangga, tanaman hias serta pepohonan yang rindang sehingga membuat suasana menjadi lebih sejuk dan nyaman serta terlihat lebih asri

\subsubsection{Keunikan Air Terjun Kuning}

Dari segi keunikan Air Terjun Kuning terdapat sumber mata air dimana sumber 4.2.1.3 Air Terjun Kuning

Air Terjun Kuning apabila dilihat dari segi fisik, memiliki tempat peristirahatan dengan luas sekitar 1 are. Tinggi Air Terjun Kuning 25 meter dengan kedalaman 3 meter. Air Terjun Dusun Kuning masih sangat alami dan belum tersentuh tangan manusia. Sehingga merupakan lokasi yang sangat cocok bagi pencari ketenangan dan kedamaian jiwa. Suara guyuran air terjun, gemericik aliran air serta nyanyian burungburung dapat menentramkan hati. Air rumusan masalah yang akan dikaji. Data yang diperoleh dari informan kemudian dibandingkan antara informan satu dengan informan lainnya sehingga diperoleh data yang dapat dipercaya kebenarannya. Selanjutnya data yang sudah terkumpul disajikan secara deskriptif-kualitatif melalui teks yang bersifat naratif dengan analisis SWOT. Setelah data disajikan, tahap selanjutnya adalah menarik kesimpulan.

mata air tersebut seringkali dimanfaatkan oleh masyarakat sekitar sebagai air minum. Mata air tersebut berasal dari aliran dasar danau batur. Selain itu juga sebelum menuju air terjun kuning terdapat air kelebutan dan sebuah pura, dimana pura tersebut dipercaya oleh masyarakat memiliki nilai spritual, air kelebutan juga bisa dinikmati oleh masyarakat sekitar dan wisatawan yang berkunjung ke air terjun kuningan. Masyarakat setempat juga percaya dan menggunakan air suci tersebut untuk melukat atau dalam agama hindu berarti proses membersihkan diri.untuk wisatawan yang ingin melukat disarankan untuk memakai pakaian adat ringan atau Adat Madya dengan dilengkapi Banten Pejati dan biasanya melukat hanya dilakukan pada hari-hari tertentu seperti Hari Purnama, Hari Tilem dan Hari besarbesar lainnya. Keunikan lain yang terdapat di air terjun kuning adalah terdapat sebuah kolam di bawah aliran air terjun Kuning yang dapat digunakan sebagai tempat untuk berendam.

Terjun Kuning dapat dinikmati sebagai lokasi penghilang penat karena keindahan serta hijaunya alam yang ada di sekitarnya. Airnya yang berasal dari sumber air pegunungan menjadikan sangat dingin dan segar ketika dibuat mandi.

\subsubsection{Pemandangan Sawah}

Air Terjun Kuning memiliki keadaan fisik yang masih sangat alami. Selain alami sebelum menuju Air Terjun Kuning, terdapat hamparan sawah yang dapat memanjakan 
mata pengunjung. Sehingga menjadi nilai tambahan bagi Air Terjun Kuning untuk menarik wisata berkunjung.

4.2.1.5 4A (attraction, accessibility, amenity dan ancilliary)

Attraction, air terjun merupakan suatu objek yang dapat dimanfaatkan untuk melakukan berbagai kegiatan menarik dan menenangkan pikiran karena air terjun terletak di daerah yang jauh dari kondisi jalan raya sehingga ketika berada di air terjun suasana akan terasa nyaman dan tenang. Di Air Terjun Kuning beberapa kegiatan yang dapat dilakukan yaitu diantaranya 1) mandi dibawah di aliran air terjun, terdapat juga kolam yang terbentuk secara alami oleh bebatuan di dekat air terjun kuning yang di dekat air terjun yang dipergunakan untuk mandi yang memiliki kedalaman 3 meter. Ketika ingin mandi dibawah air terjun kuningan di sarankan untuk melakukan acara sembahyang sesuai kepercyaan, atau menghaturkan permen di pura disana, agar diberi keselamatan dan kenyamanan ketika mandi dibawah air terjun kuningan, yang telah diyakini oleh masyarakat sekitar. 2) kegiatan pembuatan vlog Menurut wira Sulaksana, S.Kep yang bergerak dibidang pembuatan vlog (photographer) sesuai perkembangan jaman dan teknologi air terjun kuningan sangat bagus digunakan sebagai vlog, preweding, karena air terjun kuningan sangat unik yang memiliki tempat melukat, air kelebutan, dalam satu tempat area sehingga menjadi daya tarik wisatawan local maupun internasional menjadi tertarik untuk berkunjung ke air terjun kuningan. 3) kegitan melukat bagi wisatawan yang ingin melukat disana terdapat tempat sepiritual yang bisa dilakukan seperti melukat maupun bersemedi, ketika hari-hari terntuntu adanya upacara agama, tuhan yang telah diyakini oleh masyarakat sekitar melakukan pemandian (disucikan) di tempat pelukatan tersebut.Untuk saat ini kegiatan wisata bahari selain berendam belum terdapat di Air Terjun Kuning.

Amenity, fasilitas merupakan hal yang sangat memiliki peranan penting dalam suatu objek wisata karena fasilitas merupakan penunjang keberhasilan suatu objek menjadi objek wisata yang terkenal. Menurut Bapak klian Desa Adat Kuning fasilitas yang terdapat di air terjun kuning seperti restorant, tempat parkir dan office.

Restorant yang terdapat dilingkungan sekitar air terjun kuning yang biasanya digunakan untuk tempat rapat, dan untuk tempat santai setelah mengunjungi air terjun kuning, Adapun beberapa minuman yang dijual disana seperti juice, coffe \& tea, large beer, sprite, fanta, coca cola.

Ancilliary (Pelayanan Tambahan), tempat parkir merupakan fasilitas yang harus dimiliki oleh suatu objek, karena tempat parkir juga manjadi alasan bagi wisatwan untuk datang berkunjung ke suatu objek. Tempat parkir yang ada di air terjun kuning hanya satu didekat kuburan desa kuning, parkir roda dua dan roda empat dijadikan satu area parkir, sebelum masuk ke area parkir wisatawan wajib membayar tiket sebelum masuk ke area parkir senilai 10 ribu perorang.

Office memiliki peranan yang sangat penting di objek air terjun kuningan karena disana tempat informasi dan karcis masuk untuk wisata lokal dan asing, harga tiket untuk wisatawan domestik sepuluh ribu, dan untuk wisatawan mancanegara juga sepuluh ribu, harga tiket untuk wistawan lokal maupun asing tidak dibedakan biayanya, untuk pemandu wisata belum terdapat di air terjun kuningan.

Accessibility, berdasarkan hasil observasi accessibility di air terjun kuning kurang memadai sehingga accessibility ini di jabarkan ke weaknes.

\subsubsection{Weaknes}

\subsubsection{Flora dan Fauna}

Dari segi flora dan fauna terdapat berbagai jenis-jenis flora maupun fauna yang ada disekitar Air Terjun Kuning yang memiliki kelemahan yaitu beberapa jenis flora yang tumbuh disekitaran jalan menuju Air Terjun Kuning belum tertata dengan baik, pepohonan yang lebat menyebabkan wisatawan yang berkunjung susah 
melaluinya. Masyarakat sekitar perlu memerhatikannya agar akses jalannya mudah dilalui oleh pengujung. Terdapat jenis fauna seperti kera yang terlihat disekitaran Air Terjun Kuning yang berkeliaran bebas yang dapat membuat pengunjung merasa kaget jika nantinya kera mengganggu pengunjung yang datang.

\subsubsection{Keunikan Air Terjun Kuning}

Berdasarkan hasil observasi tidak terdapat weaknes atau kelemahan yang terdapat di Air Terjun Kuning sehingga pengunjung yang datang ingin menikmati indahnya Objek Wisata Air Terjun Kuning tergolong aman.

\subsubsection{Air Terjun Kuning}

Untuk akses jalan menuju Air Terjun Kuning dari parkiran Objek Wisata Air Terjun Kuning ditempuh kurang lebih 500 meter dengan menggunakan jalan setapak berupa undak-undak yang masih berbentuk tanah dan bebatuan. Akses jalan menuju Air Terjun Kuning merupakan akses jalan yang dapat menantang pengunjung wisatawan yang datang karena akses jalan dengan turunan yang sangat tajam dengan kemiringan 80 derajat dapat membahayakan wisatawan yang berkunjung. Karena terdapat banyak pepohonan besar disekitar akses jalan pada saat musim hujan banyak pohon besar tumbang sehingga dapat membuat akses jalan menjadi lebih terganggu. Objek Wisata Air Terjun Kuning sangat disarankan untuk pengunjung wisata yang senang dengan tantangan dan wisatawan yang senang mendaki. Namun kini jalan akses menunuju ke air terjun Kuning beberapa sudah dikemas dengan bahan-bahan tertentu sehingga wisatawan maupun masyarakat sekitar lebih mudah menuju air terjun kuning. Dilihat dari segi keamanan masih sangat minim karena masih belum ada pegawai yang bertugas dalam mengurus keamanan Objek wisata Air Terjun kuning.

\subsubsection{Pemandangan Sawah}

Disekitaran Air Terjun Kuning terdapat hamparan sawah dimana tidak terdapat kelemahan. Untuk saat ini pemandangan sawah masih menjadi minat untuk menarik wisatawan yang berkunjung.

4.2.2.5 4A (attraction, accessibility, amenity dan ancilliary)

Berdasarkan hasil observasi tidak terdapat weaknes atau kelemahan untuk kegiatan yang dapat dilakukan di Air Terjun Kuning mengingat banyak kegiatan yang bisa dilakukan seperti berendam, menikmati guyuran air terjun kuning, berfoto dan pembuatan Flog, dan prewedding

Amenity, berdasarkan hasil observasi tidak ditemukan penginapan, taxi, maupun ojek online, adapun yang ada untuk amenity hanya restaurant.

Accessibility berdasarkan hasil observasi Accessibility menuju air terjun kuning kurang memadai untuk di lalui oleh wisatawan apalagi saat musim hujan

\subsubsection{Oportunities}

\subsubsection{Flora dan Fauna}

Berdasarkan hasil observasi adapun peluang yang kedepannya dapat dikembangkan di Air terjun Kuning. Dari segi flora terdapat berbagai jenis tanaman hias yang hidup disekitaran Objek Wisata dapat dimanfaatkan dengan cara lebih memperhatian penataannya agar terlihat lebih indah dan rapi sehingga dapat dijadikan sebagai objek atau tempat berfoto dengan latar Air Terjun Kuning yang mengalir deras dan menjadikan moment yang sangat bagus. Dari segi fauna terdapat binatang kera yang dapat dilindungi dan dipelihara oleh masyarakat setempat dan dijadikan sebagai alat untuk menarik perhatian wisatawan. Masyarakat Desa banjar Kuning dapat menyediakan bahan makanan untuk binatang kera dan wisatawan yang berkunjung dapat memberikan makan langsung kepada kera.

4.2.3.2 Keunikan Air Terjun Kuning

Dilihat dari segi keunikan Air Terjun Kuning terdapat sumber mata air yang dipercaya oleh masyarakat sekitar digunakan sebagai tempat melukat atau membersihkan diri secara Hindu yang dapat dikembangkan lebih luas sehingga wisatawan yang berkunjung selain dapat 
menikmati Objek Wisata Air Terjun Kuning juga dapat melakukan kegiatan melukat.

4.2.3.3 Air Terjun Kuning

Dilihat dari segi kegiatan wisata di Air Terjun Kuning memiliki peluang yaitu mengembangan kegiatan wisata bahari. Objek Wisata Air Terjun Kuning yang memiliki ketinggian 25 meter dapat dilakukan kegiatan canyoning bagi wisatawan yang senang dengan tantangan.

\subsubsection{Pemandangan Sawah}

Dari hasil observasi pemandangan sawah tidak dapat dikembangkan sebagai daya tarik wisata pemandangan sawah disekitar dalam menuju air terjun kuning hanya memberikan kesan tersendiri bagi wisatawan yang mengunjunginya.

4.2.3.5 Kegiatan yang Dilakukan

Dilihat dari segi berbagai kegiatan yang dilakukan di air terjun kuning terdapat peluang yang dapat dikembangan mengingat Air Terjun Kuning memiliki kedalaman 3 meter dapat dimanfaatkan oleh masyarakat setempat dengan membuka penyewaan pelampung untuk wisatawan yang tidak bisa berenang dapat menikmati air terjun dengan cara menggunakan pelampung dan peralatan keamanan lainnya.

\subsubsection{Threats}

\subsubsection{Flora dan Fauna}

Berdasarkan hasil penelitian baik observasi maupun wawancara ditemukan threats atau ancaman yang dapat yang dapat mengancam Air Terjun Kuning sebagai daya tarik wisata dimana sekitar Objek Wisata Air Terjun Kuning terkadang muncul binatang kera yang dapat membahayakan saat wisatawan datang berkunjung kalau masyarakat setempat membiarkan begitu saja tidak dilindungi. Jika Objek Wisata Air Terjun Kuning tidak dikelola dengan baik maka wisatawan yang berkunjung mengalami penurunan. Hal tersebut dapat menjadi ancaman untuk Objek Wisata Air Terjun Kuning.

\subsubsection{Keunikan Air Terjun Kuning}

Dari segi keunikan yang terdapat di Air Terjun Kuning tidak terdapat keunikan yang menjadi sebuah ancaman terlebih lagi semua keunikan tersebut memiliki peluang untuk dikembangkan lebih jauh lagi sebagai potensi wisata.

4.2.4.3 Air Terjun Kuning

Air Terjun Kuning tidak terdapat sebuah ancaman terlebih lagi semua yang terdapat di Air Terjun Kuning tersebut memiliki peluang untuk dikembangkan lebih jauh lagi sebagai potensi wisata.

4.2.4.4 Pemandangan Sawah

Dari segi fisik pemandangan sawah beserta lingkungan sekitar juga tidak ditemukan suatu ancaman atau threats.

4.2.4.5 Kegiatan yang dilakukan

Dari segi kegiatan wisata, ditemukan sebuah ancaman berdasarkan hasil observasi Air Terjun Kuning memiliki kedalaman 3 meter, hal ini tentunya dapat merugikan bilamana terdapat wisatawan yang tengelam, oleh karena itu hal ini dapat di antisipasi oleh pengelola dengan menyediakan perlengkapan keamanan seperti rompi pelampung, dan juga meningkatkan pengawasan pada wisatawan yang sedang melakukan aktifitas berenang. Wisatawan yang ingin berenang juga dapat diarahkan untuk berenang di area yang lebih dangkal sehingga tidak membahayakan wisatawan.

\section{PEMBAHASAN}

Berdasarkan hasil penelitian diatas panelis akan membahas hasil penelitian sebagai berikut

Potensi Alam yang bersifat alamiah (natural resources) yang dimaksud adalah jenis-jenis objek wisata yang bersumber dari keadaan lingkungan alam, misalnya keadaan dan jenis flora dan fauna suatu daerah, bentang alam suatu daerah, misalnya pantai, hutan,air panas, air terjun, kawah, danau, beberapa ulasan tentang potensi alam sebagai berikut : (1) Flora atau segala macam jenis tumbuhan dan tanaman. (2) Fauna atau segala macam jenis hewan yang hidup dibagian tertentu atau periode tertentu. (3) Sumber air panas, mata air yang dihasilkan akibat keluarnya air tanah dari kerak bumi setelah dipanaskan. (4) Air terjun, aliran air yang 
berbentuk ketika aliran air jatuh dari tempat yang tinggi. Air yang jatuh akan menggerus dasar sungai hingga berbentuk cekungan menyerupai kolam. (5) Danau membentuk cekungan besar di permukaan bumi yang digenangi oleh air tawar ataupun asin. (6) Pemandangan sawah tempat yang digarap dan diairi untuk menanam padi, selain itu untuk mengairi sawah digunakan sistem irigasi dari mata air sungai atau air hujan. (7) Hutan, suatu wilayah yang memiliki banyak tumbuh-tumbuhan lebat yang berisi antara lain, pohon, semak dan sebagainya, selain itu hutan bakau atau yang lebih dikenal dengan sebutan hutan mangrove adalah ekosistem hutan daerah pantai yang terdiri dari kelompok pepohonan yang bisa hidup dalam lingkungan berkadar garam tinggi.

Berdasarkan hasil dari penelitian yang dilaksanakan pada tanggal 29 januari, 15 februari 2019 di Desa Taman Bali tepatnya di Air Terjun Kuning memang tepat dapat dijadikan salah satu Objek Wisata yang ada di Kabupaten Bangli. Objek Wisata Air Terjun Kuning ini memiliki potensi wisata alam dengan kelebihan dan keunikan oleh alamnya, jika dikembangkan dengan memperhatikan keadaan lingkungan sekitarnya niscaya akan menarik wisatawan untuk berkunjung ke Objek Wisata Air Terjun Kuning.

Strenght (Kekuatan) berdasarkan hasil penelitian Objek Wisata Air Terjun Kuning terlihat sangat indah, masih sangat alami dan asri memang memiliki berbagai jenis flora seperti tumbuhan lumut, paku, pepaya, mangga serta berbagai tumbuhan hias yang hidup disekitaran Air Terjun Kuning dan fauna seperti burung, kera, kadal, biawak yang sangat dilindungi habitatnya sehingga ketika wisatawan berkunjung ke Objek Wisata Air Terjun Kuning juga dapat menikmati berbagai jenis flora dan fauna tersebut yang dapat memanjakan mata pengunjung melihat keindahan alamnya yang masih alami dan asri. Air Terjun Kuning dijadikan sebagai sumber mata air yang dipercaya oleh masyarakat sekitar untuk membersihkan diri (melukat). Melihat keadaan Objek Wisata Air Terjun Kuning yang sangat cocok djadikan tempat selfi, pembuatan flog, praweding maka pihak pengelola harus tetap menjaga kelestariaan alamnya baik dari segi fasilitas, pelayanan serta kenyamanan wisatawan yang berkunjung

Weaknes (Kelemahan) berdasarkan hasil penelitian Objek Wisata Air Terjun kuning memang memiliki kelemahan. Kelemahan tersebut terlihat dari segi akses jalan menuju Air Terjun Kuning dimana masih menggunakan jalan setapak berbahan tanah dan bebatuan serta memiliki kemiringan 80 derajat. Kurangnya dinas pariwisata setempat dalam mepromosikan air terjun kuning serta kurangnya manajemen dari pemerintah setempat juga menjadi suatu kelemahan namun, akses jalan tersebut sudah di perbaiki untuk mempermudahkan akses jalan bagi wisatawan yang berkunjung ke Objek Wisata Air Terjun Kuning.

Opportunities (Peluang) berdasarkan hasil penelitian Objek Wisata Air Terjun Kuning adapun peluang kegiatan wisata yang dapat dikembangkan yaitu wisata bahari. Objek Wisata Air Terjun Kuning dengan memiliki kedalaman 3 meter, wistawan yang tidak bisa berenang dapat menikmati Air Terjun dengan cara menggunakan pelampung dan peralatan keamanan lainnya. Melihat peluang tersebut, pihak pengelola lebih meningkatkan fasilitas penunjang agar pengunjung merasa puas saat mengunjungi Air Terjun Kuning.

Threats (Ancaman) berdasarkan hasil penelitian Objek Wisata Air terjun Kuning ditemukan ancaman yaitu Air Terjun Kuning memiliki kedalaman 3 meter, hal ini tentunya dapat merugikan bilamana terdapat wisatawan yang tenggelam, serta disekitaran Air Terjun Kuning terkadang terdapat kera yang bermunculan. Hal tersebut dapat membuat wisatawan yang berkunjung merasa kurang nyaman. Menyadari akan pentingnya kepuasan dan kenyamanan wisatawan yang berkunjung, maka perlu memperhatikan dan 
meningkatkan kualitas Objek Wisata Air Terjun Kuning.

Apabila dikaitkan dengan teori mengenai wisata alam, tentu Air Terjun Kuning merupakan salah satu tempat rekomendasi bagi para wisatawan dan sangat cocok dikembangkan sebagai salah satu objek wisata alam karena didukung dengan keindahan alam yang masih alami, keunikan-keunikan yang dimiliki aktivitas yang dapat dilakukan serta fasilitas penunjang dari air terjun itu sendiri. Untuk menunjang pengembangan potensi yang dimiliki air terjun ini tentu harus adanya keterlibatan semua pihak mulai dari pemerintah, aparat desa, masyarakat untuk bersama-sama mengelola secara sadar wisata untuk bersama-sama mengelola secara sadar demi kepentingan desa sehingga air terjun ini bisa semakin berkembang dan banyak dikunjungi wisatawan sama halnya dengan air terjun lain yang ada di Kabupaten Bangli. Pengembangan sumber daya manusia pun perlu dilakukan sehingga mampu memberikan pelayanan yang maksimal kepada wisatawan. Kesadaraan masyarakat sebagai pengelola wisata sangat penting adanya sehingga keadaan lingkungan akan menjadi perhatian utama untuk memelihara keindahan alam terlebih air terjun kuning ini di kelilingi oleh flora yang sangat rindang.

\section{SIMPULAN DAN SARAN SIMPULAN}

Dari hasil penelitian diatas, peneliti dapat menyimpulkan bahwa air terjun kuning memiliki potensi sebagai daya tarik wisata alam di Desa Kuning dianalisis menggunakan analisis SWOT. (1) Strenght (Kekuatan) Objek Wisata Air Terjun Kuning terlihat sangat indah, masih sangat alami, memiliki berbagai jenis floradan fauna. Air Terjun Kuning dijadikan sebagai sumber mata air yang dipercaya oleh masyarakat sekitar untuk membersihkan diri (melukat). (2) Weaknes (Kelemahan)Objek Wisata Air Terjun kuning memang memiliki kelemahan.
Kelemahan tersebut terlihat dari segi akses jalan menuju Air Terjun Kuning dimana masih menggunakan jalan setapak berbahan tanah dan bebatuan serta memiliki kemiringan 80 derajat. Kurangnya dinas pariwisata setempat dalam mepromosikan air terjun kuning serta kurangnya manajemen dari pemerintah setempat juga menjadi suatu kelemahan namun, akses jalan tersebut sudah di perbaiki untuk mempermudahkan akses jalan bagi wisatawan yang berkunjung ke Objek Wisata Air Terjun Kuning. (3) Opportunities (Peluang) Objek Wisata Air Terjun Kuning adapun peluang kegiatan wisata yang dapat dikembangkan yaitu wisata bahari. Melihat peluang tersebut, pihak pengelola lebih meningkatkan fasilitas penunjang agar pengunjung merasa puas saat mengunjungi Air Terjun Kuning. (4) Threats (Ancaman) Objek Wisata Air terjun Kuning ditemukan ancaman yaitu Air Terjun Kuning memiliki kedalaman 3 meter, hal ini tentunya dapat merugikan bilamana terdapat wisatawan yang tenggelam, serta disekitaran Air Terjun Kuning terkadang terdapat kera yang bermunculan. Hal tersebut dapat membuat wisatawan yang berkunjung merasa kurang nyaman. Menyadari akan pentingnya kepuasan dan kenyamanan wisatawan yang berkunjung, maka lebih meningkatkan kualitas Objek Wisata Air Terjun Kuning.

\section{SARAN}

Berdasarkan hasil penelitian yang didapatkan, peneliti dapat memberikan beberapa saran yang sejatinya dapat dijadikan masukan untuk pengembangan objek wisata air terjun kuning yang lebih maksimal. Adapun saran yang dapat diberikan yaitu Pemerintah khususnya dinas pariwisata hendaknya memberikan dukungan kepada pelaku sadar wisata dalam mengembangkan potensi wisata air terjun kuning. Seperti misalnya bekerja 
sama dalam mengembangkan potensi wisata bahari di air terjun kuning, melakukan promosi baik di sosial media atau juga memperkenalkan air terjun kuning dalam event-event tertentu serta aksesbilitas menuju ke air terjun lebih di perhatikan karena ini merupakan suatu DAFTAR RUJUKAN

Anonim."Pengertian Potensi Wisata" Tersedia pada http://blogpariwisata.blogspot.co.id/2012/02/pengertia n-potensi-wisata

Anonim."Data Kunjungan Wisatawan ke Bangli" Dikutip dari http://disparda.baliprov.go.id Pada tanggal 24 November 2017

Anonim."Definisi Daya Tarik Wisata" Tersedia pada http://tourismeconomic.wordpress.c om/-2012/10/29/wisata-pariwisatawisatawan-kepariwisataan-unsurunsur-pariwisata

F. Ross, Glenn. 1998. Psikologi Pariwisata. Jakarta: Yayasan Obor Indonesia

I Gusti Fredi Firawan. 2016. Potensi Daya Tarik Wisata Air Terjun Nungnung Sebagai Daya Tarik Wisata Alam . Universitas Udayana. Vol 4

Ko,R. K. T. 2001. Objek Wisata Alam : Pedomen Identifikasi, Pengembangan, Pengelolaan, Pemeliharaan dan Pemasaran. Yayasan Buena Vista, Bogor.

Komang Agus Sugiarta. 2016. Analisis Potensi Ekowisata Dan Respon Masyarakat Desa Peninjoan Kecamatan Tembuku Kabupaten Bangli. Universitas Udayana. Vol. 4

Marpaung. Happy. 2002. Pengetahuan Kepariwisataan. Bandung. Alfabeta.

Nurfithriani, Ridwan. 2016 Strategi Pengembangan Objek Wisata Air Terjun Guruh Gemurai Desa Kasang Kecamatan Kuantan Mudik Kabupaten Kuantan Singingi. University Pekanbaru Indonesia. Vol 6 kenyamanan tersendiri bagi pengunjung yang datang ke air terjun kuning untuk meningkatkan kualitas dalam pengembangkan potensi wisata alam air terjun kuning.

Pendit, S. 1994. Ilmu Pariwisata Sebuah Pengantar Perdana. Jakarta: Pradnya Paramita

Pitana, I Gede dan Ketut Surya Diarta. 2009. "Pengantar IImu Pariwisata" Yogyakarta : CV ANDI OFFSET

Suharsaputra, Uhar. 2012. Metode Penelitian : Kuantitatif, Kualitatif dan Tindakan. Bandung : PT Refika Aditama

Sugiyono, 2015 . Metode Penelitian Kombinasi (Mix Methods).

Bandung:Alfabeta.

Undang-undang Republik Indonesia Nomor 10 Tahun 2009 tentang Kepariwisataan

Wiwoho, B., Ratna, P., dan Yulia, H. 1990. Pariwisata, Citra dan Manfaatnya. PT Bina Rena Pariwara. Jakarta.

Yoeti, H. Oka A. 1999 "Pengantar Ilmu Pariwisata". Jakarta : Pertja 